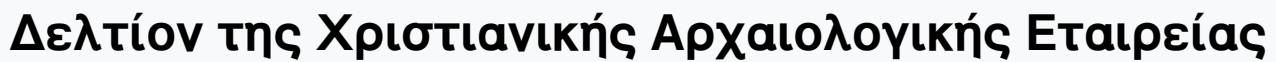

Tóp. 9 (1979)

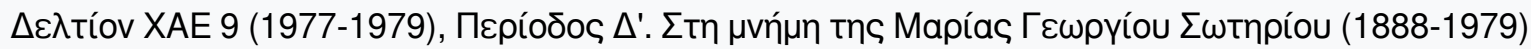

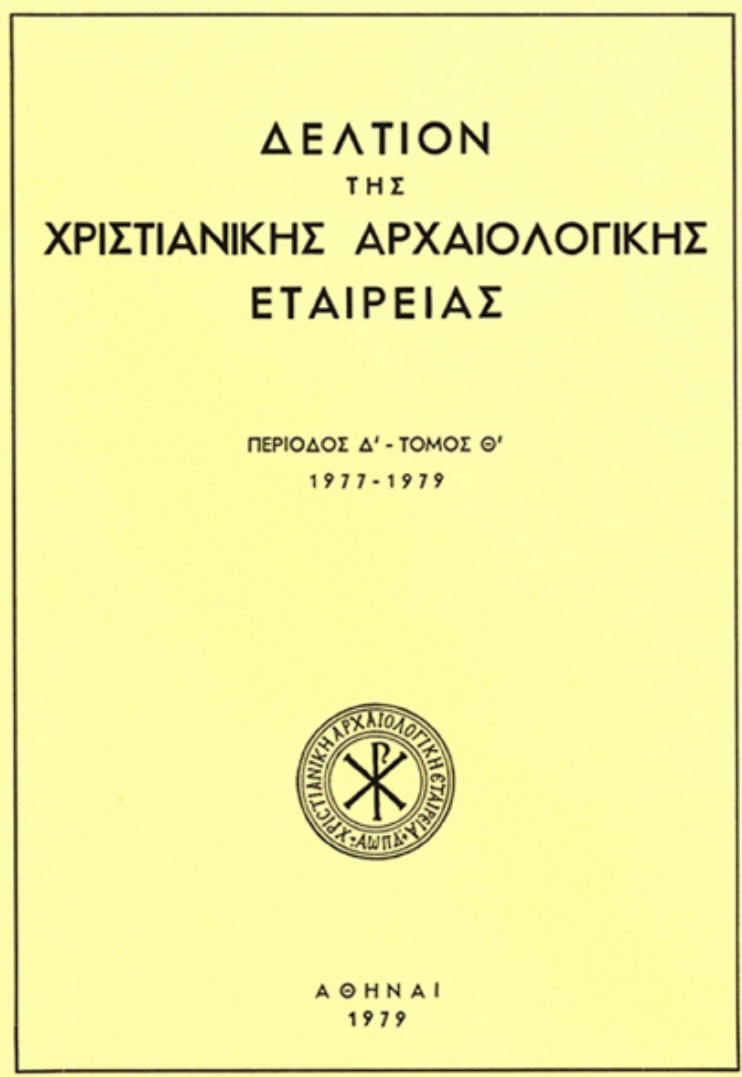

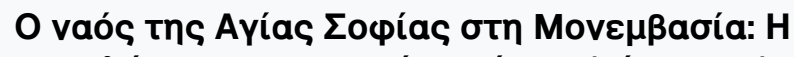

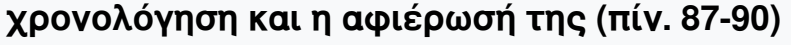

Haris KALLIGA

doi: $\underline{10.12681 / \text { dchae. } 877}$

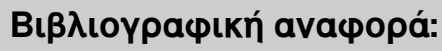

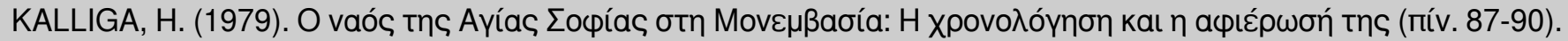

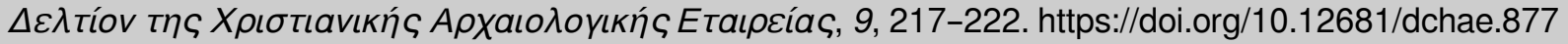




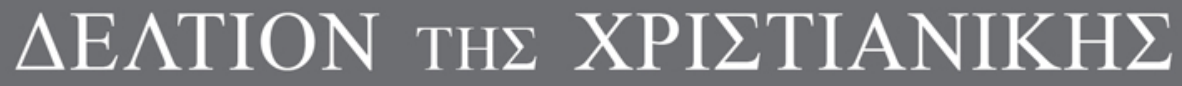 APXAIO $\Lambda$ OГIKH $\Sigma$ ETAIPEIA $\Sigma$}

The Church of Haghia Sophia at Monemvasia: Its Date and Dedication (pls 87-90)

Haris KALLIGA

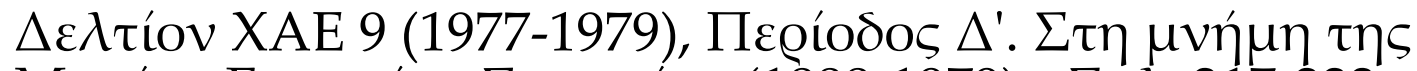

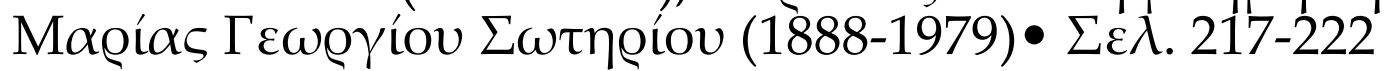
A@HNA 1979 


\section{THE CHURCH OF HAGHIA SOPHIA AT MONEMVASIA: ITS DATE AND DEDICATION}

(PLS $87-90)$

The purpose of this paper is to identify the octagonal-domed church, known as Haghia Sophia, built within the citadel of Monemvasia ( $\mathrm{Pl}$. 87a), with the church dedicated to the Theotokos the Hodhighitria, known from written sources of various periods to have existed there.

A strong local tradition attributes the construction of Haghia Sophia to the emperor Andronikos II Palaiologos, the «protector» of Monemvasia, as he is locally called, during a stay of his in the town ${ }^{1}$. This would mean that the church was constructed in the 13th century, a date accepted by some scholars, like Traquair, and Krautheimer ${ }^{2}$. But because of its stylistic relationship to other churches of the same group and particularly Daphni, it is generally considered to be a building of the 12th century ${ }^{3}$. No documents on Haghia Sophia seem to have survived and no mention is found in written sources of a church dedicated to Haghia Sophia before the 19th century and indeed not before 1821, when Monemvasia was liberated from the Turks. Many details are given for example in the well known book by Buchon, La Grèce Conti-

1. Andronikos II Palaiologos is connected with an Hodhighitria in Monemvasia, not the church, but an icon. After a visit to the town he sent as a gift from Constantinople to the «citizens» of Monemvasia a precious icon of the Virgin Hodhighitria.

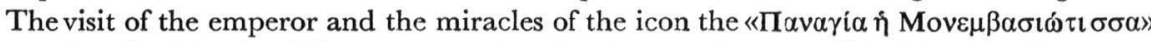
are described in detail in a manuscript of unknown date, published by $\mathrm{N}$. $\mathrm{K}$ a t r a-

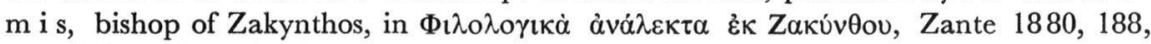

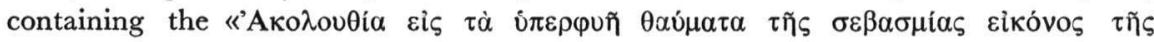

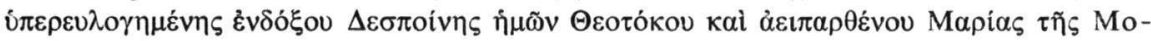

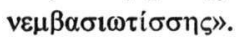

2. R a m s a y Tra qu a i r, Laconia I. The Mediaeval Fortresses, BSA 12 (1905 1906), 273. R. K r a u th e i m e r, Early Christian and Byzantine Archite cture, The Pelican History of Art, 1965, 294.

3. For example: G. Millet, L'école grecque dans l'architecture byzantine. Paris 1916, 116, 234n. 7. E. S t i k a s, L'église byzantine de Christianou, Paris 1951, 41 and at the list of octagonal domed-churches, at the end of the book, no page indication. 
nentale et la Morée $\mathrm{e}^{4}$. An interesting reference is contained in a book written by K. Papamichalopoulos, published in Athens in 1874, called, Siege and taking of Monemvasia by the Greeks in 1821 (p. 57). Papamichalopoulos maintains that the dedication to Haghia Sophia is due to the fact that the church is an exact copy of Haghia Sophia of Constantinople - which of course it is not. From this interpretation, no doubt very flattering to the inhabitants of Monemvasia, my suspicions as to the dedication to Haghia Sophia began.

In the earlier written sources there is no mention of a church known as Haghia Sophia, even though we find, scattered here and there, mentions of other churches in Monemvasia. For example in the Life of Saint Theodore of Kythera we are informed about the existence of two churches: one dedicated to the Theotokos, called «tes Diakonias», and one dedicated to the Prodromos ${ }^{5}$. The life of Saint Martha, abess of a monastery in Monemvasia is one of the many narrations written in the 10th century by the bishop Paul of Monemvasia, a native of the town ${ }^{6}$. In the title there is a mention of the Church of Hodhighitria ${ }^{7}$ :

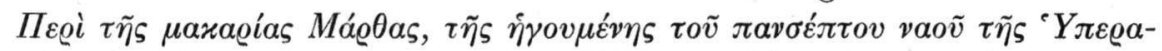

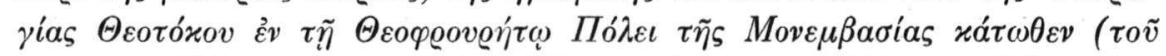

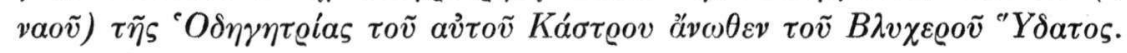

Or: "Concerning the blessed Martha, abess of the Most Venerable Church of the Most Holy Virgin within the God-guarded town of Monemvasia, below (the church of) Hodhighitria of the same Castle above the Brackish water».

N. Bees (B⿱亠幺十ৎ) proposed an identification of the site of Hodhighitria in his long article, published in 1934, which is mainly concerned with the importance of the cult of Elkomenos and of Chryssaphitissa in the region of Monemvasia ${ }^{8}$. He believes that the cult of Hodhighitria was very important before it was replaced by that of Chryssaphitissa and that the actual church of Chryssaphitissa, near the sea-wall of the low-

4. Paris 1843, 413 - 414: «...Un grand couvent fondé par l'empereur Andronic quelques années après la cession faite par Guillaume de Villehardouin... placé sous l'invocation de Sainte Sophie».

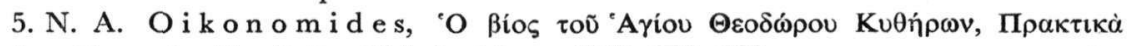

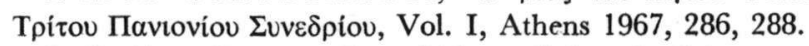

6. G. D a Cost a - L o u ille t, Saints de Grèce aux VIIIe, IXe et Xe siècles, 7: Vie de Sainte Marthe de Monembasia (Xe siècle), Byzantion 31 (1961), 434 -436.

7. A. Ko m in is, Paolo di Monembasia, Byzantion 29 - 30 (1959 - 1960), 247.

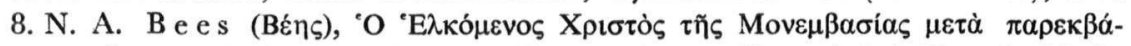

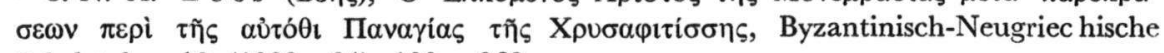
Jahrbücher 10 (1933 - 34), $199-262$. 
er town, was erected on the site of the old Hodhighitria ${ }^{9}$ (Pl. 87b). But he produces no evidence for this. On the contrary his view is not justified by the text of the life of Martha. Bees somehow considers the monastery of the Theotokos where Martha was Superior and the Hodhighitria to be one and the same, whereas the text speaks clearly of two different establishments: the church of Hodhighitria and the monastery of the Theotokos. The church of Hodhighitria is used as a landmark, together with another landmark the "Vlycheron Hydor» to define the exact site of the monastery of the Theotokos, which is placed between Hodhighitria and the Spring. By his use of the expression «Kর́ $\tau \omega \theta \varepsilon v \tau \tilde{\eta} \varsigma$

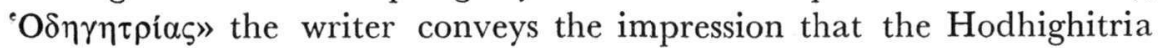
was situated on a height. Furthermore he makes the distinction between town and citadel, where the Hodhighitria must have been, by the use of the words "polis» to define the site of the monastery of the Theotokos and «Kastro» for Hodhighitria. Elsewhere in the same text we find the

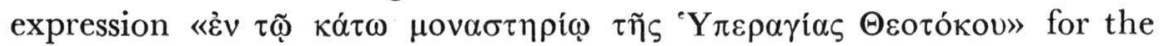
monastery where Martha resided, confirming again the existence of two churches dedicated to the Virgin: one in the town and another, the Hodhighitria, in the citadel (Pl. 88a).

That the Hodhighitria was situated in the citadel is further confirmed by another text, written in the 16th century, contained in the manuscript Vaticanus Latinus $4789^{10}$. We read there: «...is ton goulan tis Monovasias is tin Odiitrian eclisian Omorfi». This leaves no doubt as to where Hodhighitria was located.

From a note written in the 17 th century by Ioannes Likinios, a member of the Monemvasiote family of the Likinioi, we are informed that in 1606 the Hodhighitria had been built for exactly 456 years. This note is contained among others concerning Monemvasia in the manuscript Kutlumus $220^{11}$. This information makes it clear that the church of Hodhighitria was still standing in the 17th century. Furthermore, contemporary views of the town show only one important church stand-

9. Ibid. $202-206$.

10. Published by V. L a u r e n t, Le Vaticanus Latinus 4789. IV. Histoire et alliances des Cantacuzènes aux XIVe - XVe siècles, REB 9 (1951), 71. The same text mentions the tomb of a Kantakouzenos, a king or a despot («vasilef»), in the church of Hodhighitria in Monemvasia. The tomb could be connected with the construction of the Stoa in the southern part of the church.

11. B e es, op. cit. 206, P. S chreiner, Die Byzantinischen Kleinchroniken, Corpus Fontium Historiae Byzantinae XII/1 and 2, I, Wien, 1975, 320, n. 41, 6; II,

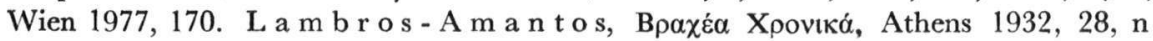
$13,20$. 
ing on the citadel on a site corresponding with that of Haghia Sophia ${ }^{12}$ (Pl. 88b).

The confirmation that this church, Haghia Sophia, is the Hodhighitria lies on the south wall of the sanctuary: there, among many graffitti of boats and galleys, the word «Hodhighitria» is repeated in four different places and, in another case, it has been started but not completed (Pls $90 \mathrm{a}, \mathrm{b}, \mathrm{c})$.

The date of construction of the Hodhighitria, can be calculated accurately from the above mentioned note by Ioannes Likinios. He says that in 1606 the church was 456 years old, which means that it must have been built in 1150 . It is very interesting to observe that this date coincides with the dating accepted on stylistic grounds ${ }^{13}$.

It is not difficult to understand how the dedication to Hodhighitria was forgotten in the 18th century. During the second Turkish occupation of Monemvasia, between the years 1715 and 1821, there were no Greeks living in the citadel. Furthermore, during the last decades of the 18th century Monemvasia was depopulated as a consequence of the Albanian invasions that followed the uprising of the Greeks in 1770, known as «Orlofika». William Martin Leake, who visited Monemvasia in March 1805, was a witness to the depopulation. "There are», he says, «about 300 houses in the town, (of Monemvasia), and 50 in the castle: all except about six, are Turkish. Before the Russian invasion of the Morea there were 150 families, but they...fled after that event...». In another part of his book he described the citadel: «There still exist some good cisterns and the remains of two or three hundred houses and magazines; among these is the ruin of a large church which has been converted into a mosque» ${ }^{14}$. So it seems that by his time, the dedication to Hodhighitria had been forgotten. A contemporary of Leake Gheorghios Kyriakos Kosmakes, who was born in Monemvasia in 1770, left a very detailed list of all its churches ${ }^{15}$, but he gives no information whatever about the site and the dedication of any of the churches in the citadel.

12. Cor onel1i, for example, in Morea, Negroponte and adjacenze, Venice ca. 1708 .

13. On the sources used for these notes of the Kutlumus 220, the authors and their credibility see P. Schreiner, op. cit. 318 and P. Schreiner, Note sur la fondation de Monemvasie en 582 - 583, Travaux et Mémoires 4 (1970), 471 - 475.

14. W. M. L e a ke, Travels in the Morea, Vol. I, London 1830, 204, and $218-219$.

15. Unpublished. Bees was planing a publication. I used a manuscript copy made by Mrs Lina Andrianopoulou from Monemvasia from Bees' notes in 1942. 
So obviously, when Monemvasia was liberated in 1821, the old church was returned to Christian use and was dedicated to Haghia Sophia, probably for the reasons proposed by Papamichalopoulos ${ }^{16}$.

HARIS KALLIGAS

16. To the left and right of the lintel of the door from the narthex to the main church, lies the following painted inscription in verse, under a damaged painting of Christ with two angels (Pl. 90):

\section{+ T $\Omega$ THN CEBACTIN EYCEBOC} ICTOPIKO[T][I] MVAAC ANOIEON

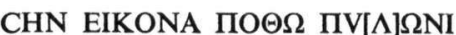

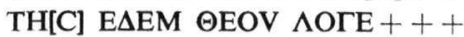

The inscription refers to the donor of the painting, either a member of the family of Pothos, or a well known personality who had the pious desire to decorate the entrance to the church.

As to the dedication of the church not to the Christ, as the painting might suggest, but to the Virgin, there is at least one similar case: the Katholikon of Nea Moni in Chios, dedicated to the Dormition of the Virgin, used to have a painting of Christ above the main door from the narthex to the main church.

Part of the inscription of Monemvasia, with many errors, was published by $\mathrm{K}$.

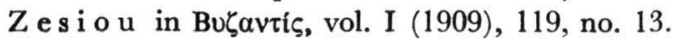




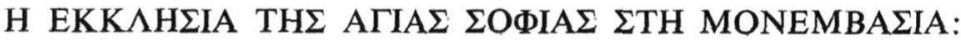 H XPONO}

(חIN. 87 - 90)

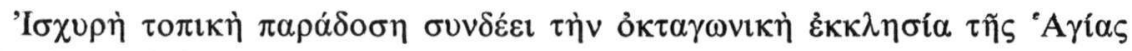

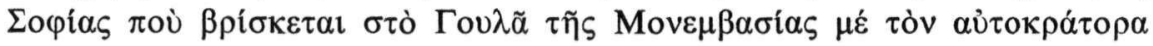

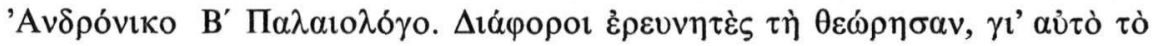

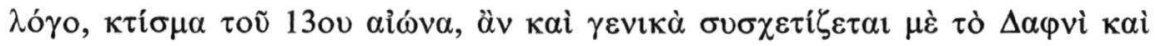

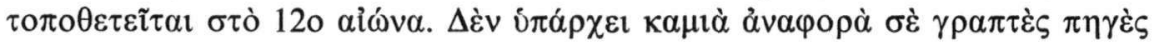

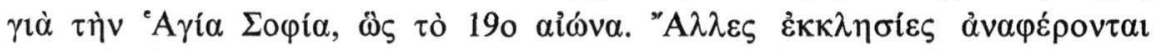

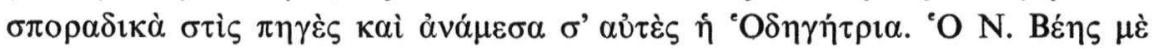

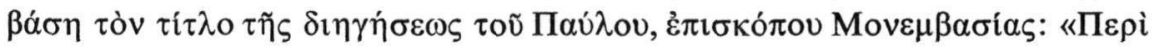

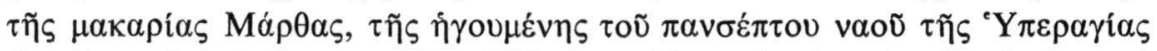

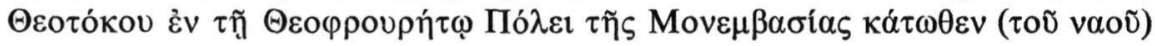

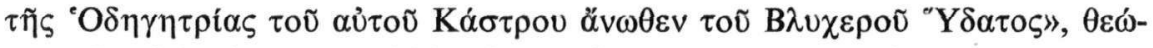

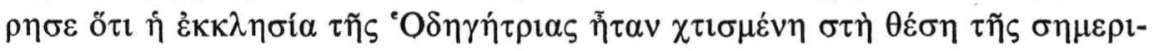

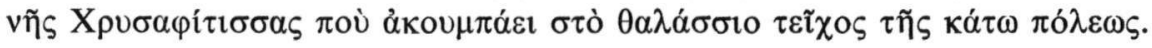

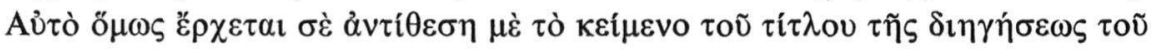

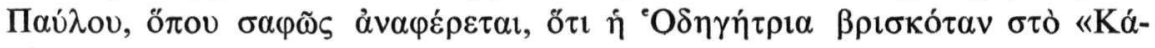

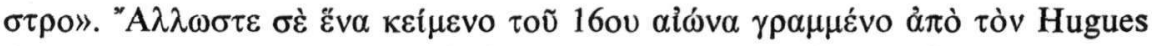

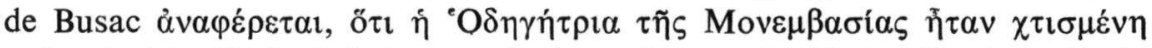

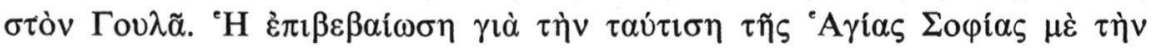

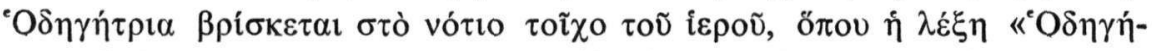

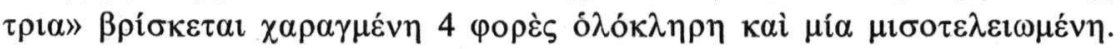

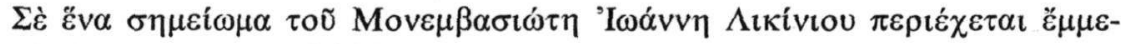

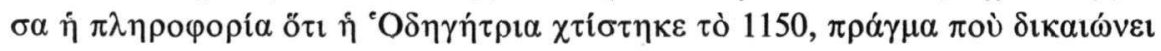

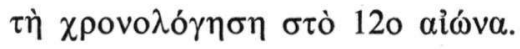

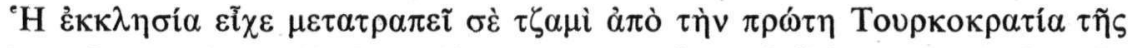

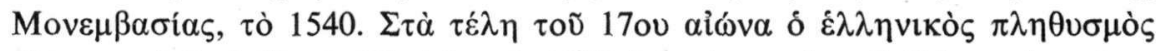

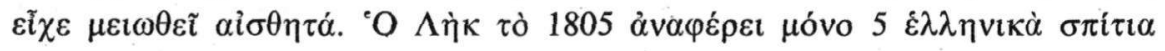

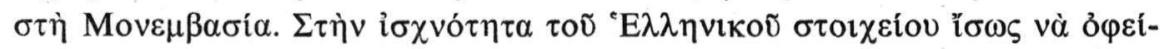

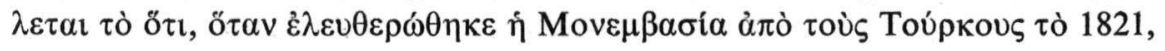

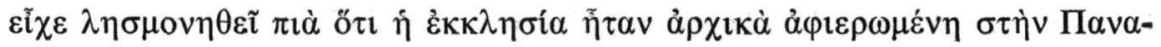

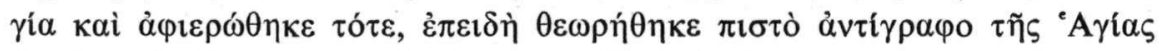

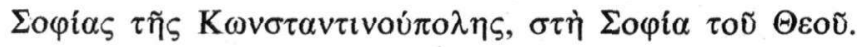



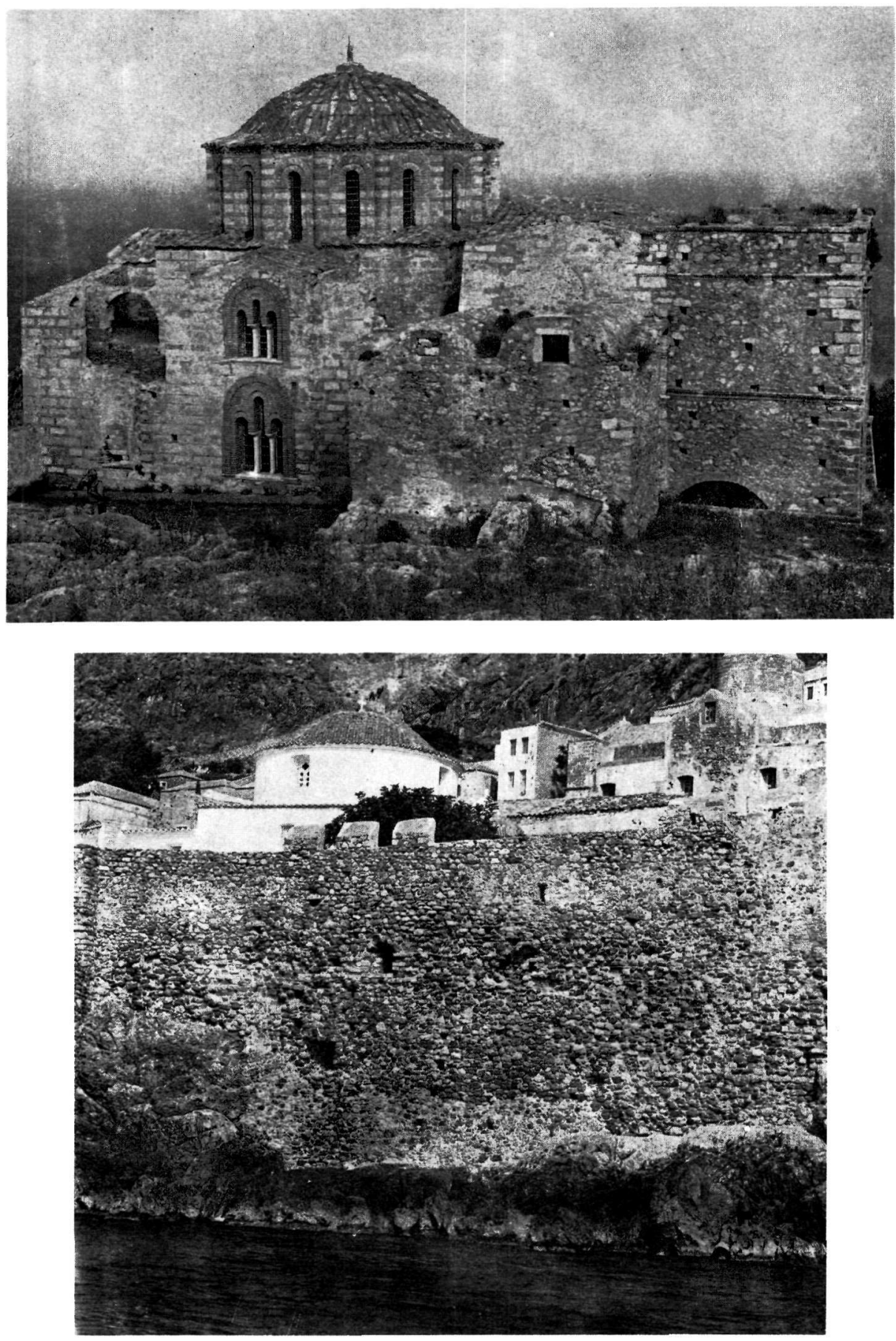

a. Haghia Sophia at Monemvasia. b. The church of Chryssaphitissa near the sea-wall of the lower town of Monemvasia. 

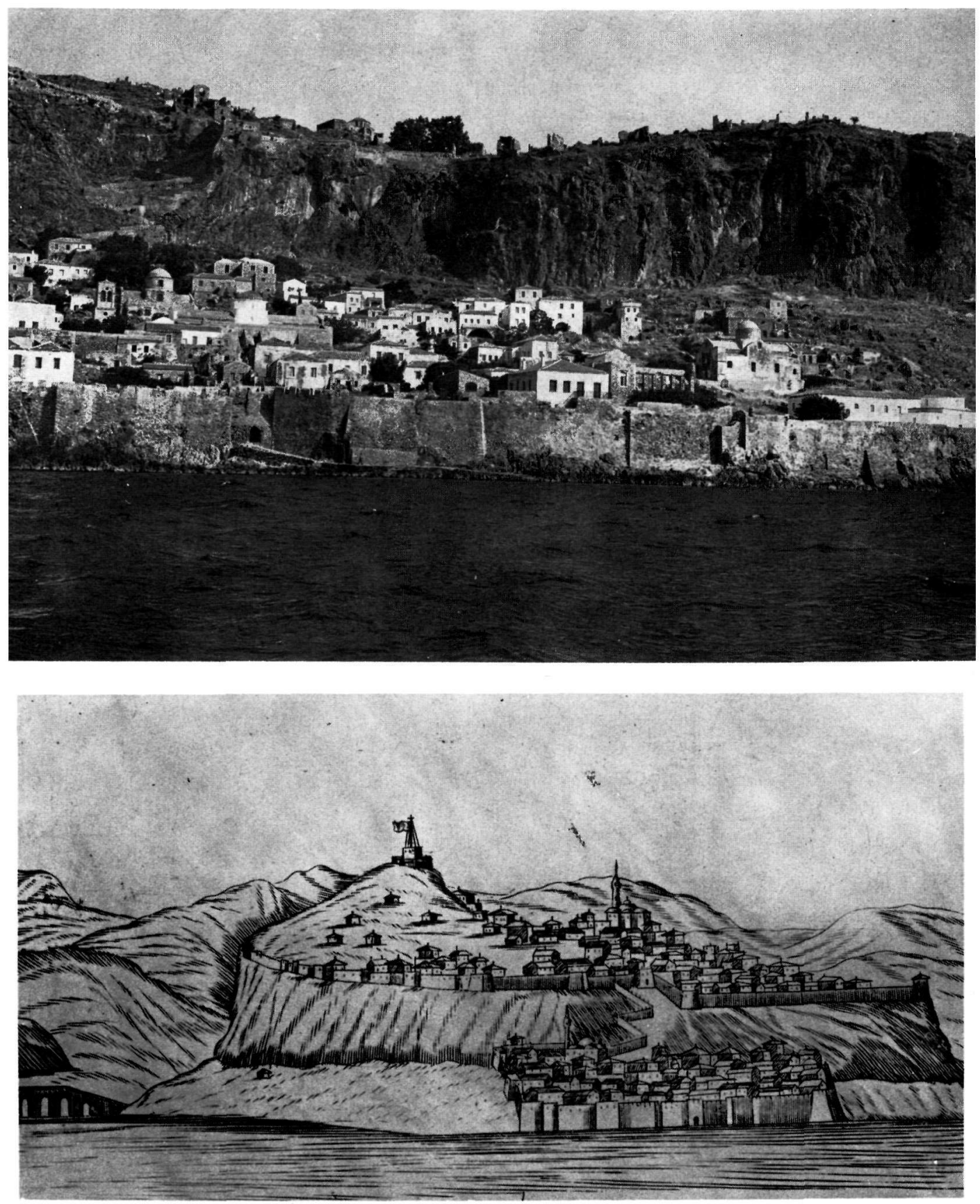

a. View of Monemvasia from the sea, with Chryssaphitissa on the right end of the lower town and «Haghia Sophia» in the citadel. b. View of Monemvasia from the book: Morea, Negroponte and adiacenze, by $\mathrm{V}$. Coronelli (Gennadeion Library). 

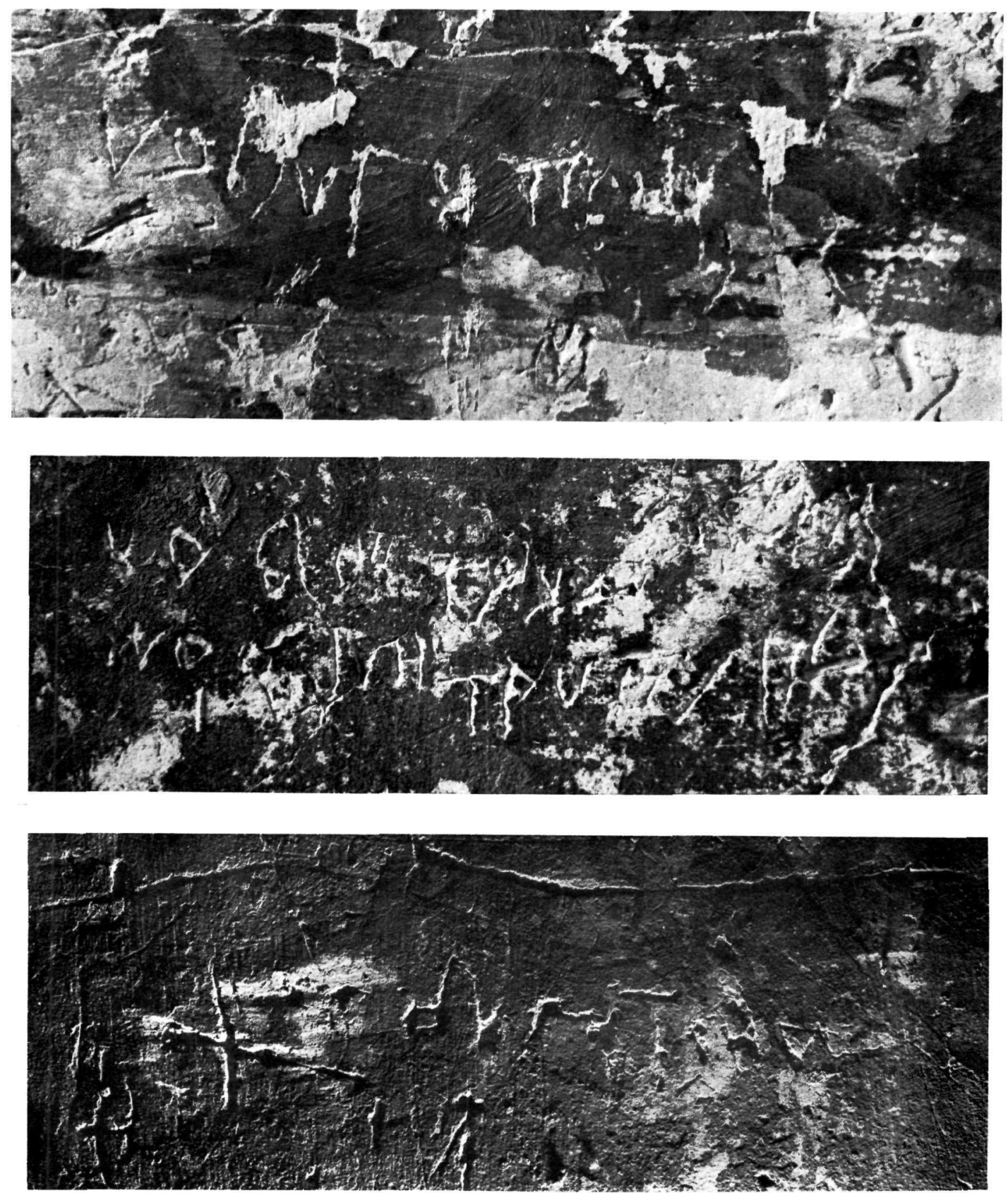

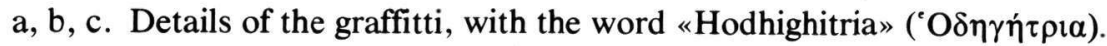



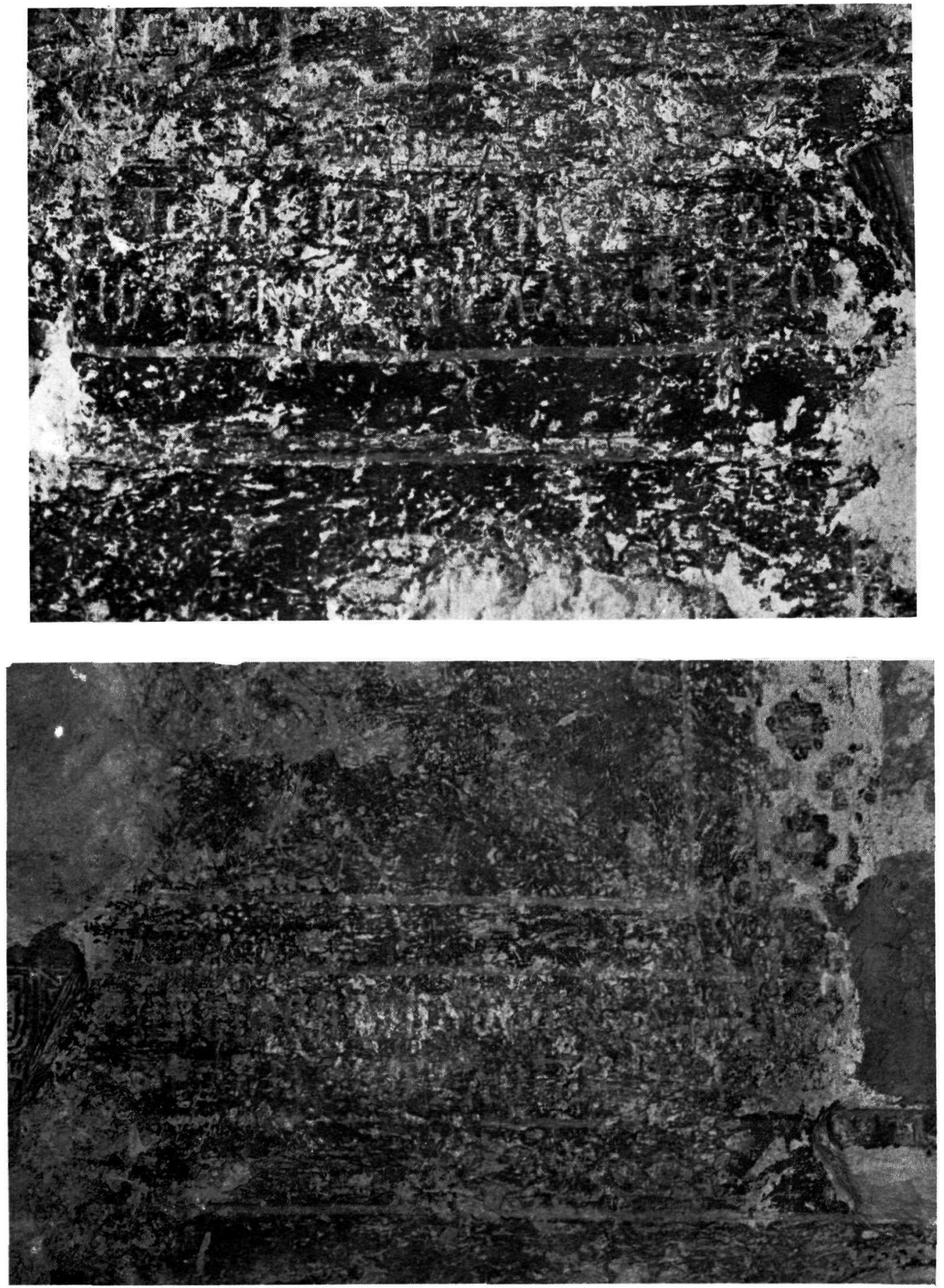

Inscription in the narthex of Haghia Sophia. a. To the left of the lintel. b. To the right of the lintel of the door. 